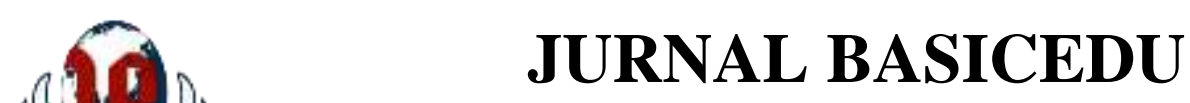

Volume 5 Nomor 6 Tahun 2021 Halaman 5885 - 5891

Research \& Learning in Elementary Education

https://jbasic.org/index.php/basicedu

PAVLSIIAS

\title{
Pengembangan Bahan Ajar Pencemaran Lingkungan Berbasis PBL terhadap Kemampuan Berpikir Kritis Siswa
}

\author{
Nonci Melinda uki ${ }^{1}$, Markus O. Here Bire ${ }^{2}$ \\ STKIP Soe, Indonesia ${ }^{1,2}$ \\ E-mail: $\underline{\text { noncimelindauki@gmail.com }}{ }^{1}$, herebire.stkipsoe@gmail.com ${ }^{2}$
}

\begin{abstract}
Abstrak
Penelitian ini bertujuan untuk menghasilkan bahan ajar pencemaran lingkungan berbasis PBL yang valid, praktis dan efektif untuk digunakan dalam proses pembelajaran. Jenis penelitian ini adalah Research \& Development (R\&D). Desain penelitian yang digunakan adalah pre-experimental design (One-shot case study). Rancangan uji coba bahan ajar penceraman lingkungan berbasis PBL menggunakan tiga tahap yaitu validasi ahli, uji coba skala kecil dan uji skala besar. subjek penelitian adalah seluruh siswa kelas X MIA 1 SMK Kristen 1 Soe yang berjumlah 36 orang. Data diperoleh dari instrumen pengumpulan data dan di analisis secara deskriptif. Hasil penelitian menunjukkan bahwa bahan ajar pencemaran lingkungan berbasis PBL sudah memiliki kualitas yang valid dan layak untuk digunakan. Hal ini berdasarkan rata-rata hasil validasi ahli materi dan ahli media adalah 93.48 yang termasuk kategori sangat valid. Bahan ajar pencemaran lingkungan berbasis PBL praktis untuk digunakan dalam kegiatan pembelajaran. Hal ini berdasarkan rata-rata hasil analisis dari respon guru dan siswa adalah 83.48 yang tergolong dalam kategori Sangat Praktis. Bahan ajar pencemaran lingkungan berbasis PBL efektif untuk meningkatkan kemampuan berpikir kritis siswa . Hal ini di lihat dari analisis rata-rata kemampuan berpikir kritis siswa adalah 79.52 yang tergolong dalam kategori baik. Berdasarkan hasil penelitian tersebut maka dapat disimpulkan bahwa bahan ajar pencemaran lingkungan berbasis PBL yang di kembangkan valid, praktis dan efektif untuk digunakan dalam proses pembelajaran.
\end{abstract}

Kata Kunci: Bahan Ajar, PBL, Kemampuan Berpikir Kritis.

\begin{abstract}
The current study aims at producing valid, practical, and effective PBL-based-teaching material about Pollution to be used in teaching and learning process. This is a Research \& Development $(R \& D)$ with preexperimental design (One-shot case study). The field test design of the PBL-based-teaching material about Pollution uses three steps consisting of expert validation, small scale field test, and big scale field test. The subject of this research was 36 students of grade X Science 1 SMK Kristen 1 Soe. The data was gathered using data collection instrument and was analyzed descriptively. The result of the research shows that teaching material about pollution based on PBL is valid to be used. This result is based on the average of teaching material expert and media expert validation result with score 93.48 and is categorized very valid. This PBL-based-teaching material is practical to be used in teaching and learning process. This is based on the average of the analysis result of teachers and students responses with score 83.48 and is categorized very practical. The PBL-Based-Teaching Material is effective to improve students' critical thinking skill. This is based on the average of students' critical thinking skill analysis which is scored 79.52 and is categorized good. Based on the result of the research, it can be concluded that the developed PBL-based-teaching material is valid, practical, and effective to be used in teaching and learning process.
\end{abstract}

Keywords: Teaching Material, PBL, Critical Thinking Skill.

Copyright (c) 2021 Nonci Melinda uki, Markus O. Here Bire

Corresponding author :

Email: noncimelindauki@gmail.com

DOI : https://doi.org/10.31004/basicedu.v5i6.1730

ISSN 2580-3735 (Media Cetak)

ISSN 2580-1147 (Media Online)

Jurnal Basicedu Vol 5 No 6 Tahun 2021 p-ISSN 2580-3735 e-ISSN 2580-1147 
5886 Pengembangan Bahan Ajar Pencemaran Lingkungan Berbasis PBL terhadap Kemampuan Berpikir Kritis Siswa - Nonci Melinda uki, Markus O. Here Bire

DOI : https://doi.org/10.31004/basicedu.v5i6.1730

\section{PENDAHULUAN}

Salah satu upaya dalam meningkatkan mutu pendidikan adalah dengan melakukan berbagai inovasi dalam kurikulum, saat ini salah satunya adalah dengan memasukan pendidikan kecakapan hidup atau life skil, soft skil dan pendidikan berkarakter (Setyowati \& Subali, 2011). Ketiga pendidikan tersebut diharuskan mampu mengembangkan kemampuan berpikir tingkat tinggi, Salah satunya kemampuan berpikir kritis. Sejalan dengan pendapat (Sudarma, 2013) yang mengatakan bahwa pada dasarnya manusia adalah makluk yang dapat menciptakan kreativitas dan mampu berpikir secara kritis dalam menghasilkan sesuatu yang inovatif, didukung oleh karakter yang mampu dalam mengendalikan inovasi itu sendiri sehingga kemampuan berpikir kritis menjadi hal yang sangat penting untuk dimunculkan pada setiap individu terutama siswa. Hal ini juga didukung oleh pendapat (Liliasari, 2011) yang menyatakan bahwa kemampuan berpikir yang menjadi dasar dari kemampuan berpikir lainnya adalah kemampuan berpikir kritis. Kemampuan berpikir kritis berpengaruh terhadap terbentuknya sikap ilmiah siswa (Damanik \& Bukit, 2013).

Berdasarkan peraturan menteri pendidikan nasional (Permendiknas) tentang standar proses, yang mengatur tentang perencanaan proses pembelajaran yang mensyaratkan bagi pendidik pada satuan pendidikan untuk mengembangkan rencana pelaksanaan pembelajaran (RPP). Salah satu elemen dalam RPP adalah sumber belajar. Berdasarkan hal tersebut guru diharapkan untuk mengembangkan bahan ajar sebagai salah satu sumber belajar (Departemen Pendidikan Nasional, 2008). Hal ini didukung oleh pendapat (Lestari, 2013) yang mengatakan bahwa kemampuan guru dalam merancang bahan ajar menjadi hal yang sangat berperan dalam menentukan keberhasilan proses belajar dan pembelajaran melalui sebuah bahan ajar.

Pembelajaran Biologi tidak dapat dipisahkan dari pemanfaatan bahan ajar Biologi sebagai sumber belajar. Bahan ajar Biologi idealnya mengacu pada hakikat sains yaitu produk, proses, dan sikap. siswa melalui bahan ajar Biologi diharapkan mampu menguasai produk sains seperti konsep-konsep, menggunakan metode ilmiah untuk menyelesaikan masalah-masalah sains, dan memiliki sikap positif terhadap sains (Toharudi, U. et al., 2011).

Berdasarkan hasil observasi di SMA Kristen 1 Soe menunjukkan bahwa bahan ajar materi pencemaran lingkungan belum tersedia, selama ini proses pembelajaran di dalam kelas hanya mengandalkan buku paket yang sudah tersedia di sekolah dan juga guru belum menerapkan model pembelajaran yang inovatif dimana dalam proses pembelajran guru masih menggunakan metode ceramah sehinga kemampuan berpikir kritis siswa rendah. Penurunan kemampuan berpikir kritis siswa pada materi pencemaran lingkungan disebabkan karena guru kurang optimal memanfaatkan lingkungan sebagai sumber belajar dalam proses pembelajaran. Pembelajaran pada materi pencemaran lingkungan cenderung teoritis sehingga siswa kurang optimal dalam memahami konsep-konsep yang saling berkaitan dan kompleks.

Berdasarkan hasil observasi tersebut maka diperlukan solusi untuk mengatasi permasalahan pembelajaran. Salah satu alternatif solusi yaitu pengembangan bahan ajar biologi yang diharapkan mampu memberdayakan kemampuan berpikir kritis siswa. Bahan ajar yang dikembangkan akan berorientasi pada suatu model pembelajaran. Salah satu model pembelajaran yang dapat digunakan adalah dengan menerapkan pembelajaran berdasarkan masalah atau Problem Based Learning (PBL).

Model pembelajaran PBL merupakan salah satu pendekatan pembelajaran yang digunakan untuk merangsang berpikir tingkat tinggi siswa dalam situasi yang berorientasi pada masalah dunia nyata (Rusman, 2012).

Model PBL juga merupakan model pembelajaran yang menuntut siswa mengembangkan keterampilan berpikir, pemecahan masalah dan keterampilan intelektual, menumbuhkan kemampuan kerja sama, dan mengembangkan sikap sosial (Hamruni, 2011). Pembelajaran dengan model PBL diharapkan memberikan kesempatan pada siswa untuk dapat meningkatkan keterampilan berpikir kritisnya. 
5887 Pengembangan Bahan Ajar Pencemaran Lingkungan Berbasis PBL terhadap Kemampuan Berpikir Kritis Siswa - Nonci Melinda uki, Markus O. Here Bire

DOI : https://doi.org/10.31004/basicedu.v5i6.1730

Berdasarkan uraian tersebut, maka telah dilakukan penelitian dengan judul "Pengembangan Bahan Ajar Pencemaran Lingkungan Berbasis PBL terhadap kemampuan berpikir kritis siswa.

Tujuan dari penelitian ini adalah untuk mengetahui validitas, kepraktisan dan keefektifan bahan ajar pencemaran lingkungan berbasis PBL terhadap kemampuan berpikir kritis siswa.

\section{METODE}

\section{Metode dan Desain Penelitian}

Metode penelitian ini yaitu pengembangan atau Research and Development $(R \& D)$. Desain penelitian yang digunakan adalah pre-experimental design (One-shot case study) (Hamruni, 2011). Subjek dalam penelitian ini siswa kelas X MIA 1 yang berjumlah 36 orang.

\section{Prosedur Penelitian}

Prosedur penelitian pengembangan bahan ajar menggunakan langkah-langkah pengembangan model Borg and Gall (Hamruni, 2011).

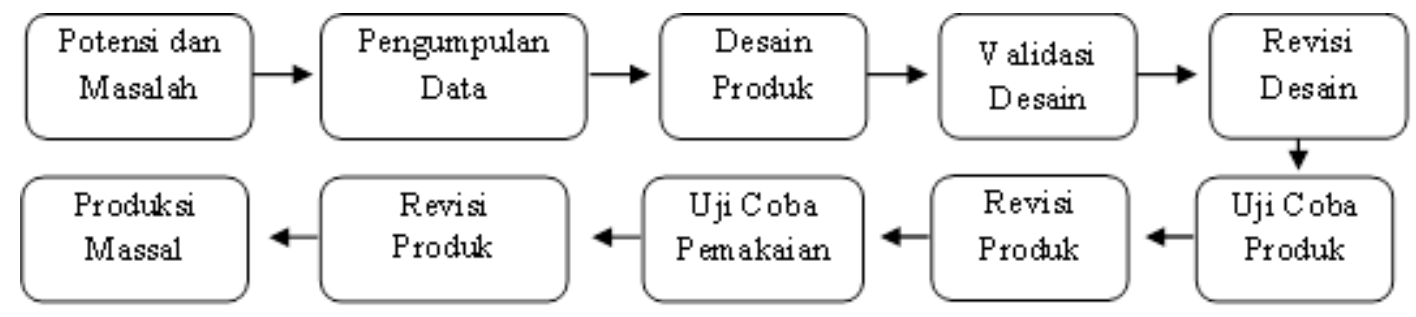

\section{Instrumen pengumpulan data}

Instrumen yang digunakan dalam penelitian pengembangan bahan ajar ini adalah lembar validasi bahan ajar, kuesioner respon guru dan siswa dan lembar observasi kemampuan berpikir kritis siswa.

\section{Teknik analisa data}

Adapun teknik analisa data yangdilakukan dalam penelitian ini adalah:

\section{Analisis validasi ahli}

Analisis valiasi ahli di lakukan dengan cara:

a. Menghitung skor validitas dari hasil validasi ahli menggunakan rumus:

$$
\mathrm{P}=\frac{\text { Perolehan Skor Validasi } 4 \text { Validator }}{\text { Total Skor Maksimal }} \times 100 \%
$$

b. Hasil Validasi yang telah diketahui presentasinya dapat dicocokan dengan nilai kategori validasi bahan ajar yang disajikan pada tabel 1 .

Tabel 1. Nilai kategori validitas bahan ajar

\begin{tabular}{ll}
\hline Nilai Persentase & Kategori \\
\hline $80 \%<\mathrm{Pv} \leq 100 \%$ & Sangat valid \\
\hline $60 \%<\mathrm{Pv} \leq 80 \%$ & Valid \\
\hline $40 \%<\mathrm{Pv} \leq 60 \%$ & Cukup valid \\
\hline $20 \%<\mathrm{Pv} \leq 40 \%$ & Kurang valid \\
\hline $0 \%<\mathrm{Pv} \leq 20 \%$ & Tidak valid \\
\hline \multicolumn{2}{c}{ Sumber: Riduwan, 2010 }
\end{tabular}


5888 Pengembangan Bahan Ajar Pencemaran Lingkungan Berbasis PBL terhadap Kemampuan Berpikir Kritis Siswa - Nonci Melinda uki, Markus O. Here Bire

DOI : https://doi.org/10.31004/basicedu.v5i6.1730

Kualitas bahan ajar dinyatakan siap diaplikasikan jika persentase dari hasil validasi oleh validator berada pada kategori interval minimal valid. Nilai persentase validasi Bahan ajar diperoleh dari nilai ratarata empat orang tim validator.

\section{Uji kepraktisan bahan ajar}

Uji kepraktisan bahan ajar menggunakan instrumen respon guru dan siswa yang dianalisis menggunakan rumus:

$$
\mathrm{P}=\frac{\text { Perolehan Skor Validasi } 4 \text { Validator }}{\text { Total Skor Maksimal }} \times 100 \%
$$

Hasil persentasi skor akan dikonversikan berdasarkan nilai kategori disajikan pada tabel 2.

Tabel 2. Nilai kategori penilaian respon guru dan siswa

\begin{tabular}{ll}
\hline Nilai Persentase & Kategori \\
\hline $80 \%<\mathrm{Pv} \leq 100 \%$ & Sangat praktis \\
\hline $60 \%<\mathrm{Pv} \leq 80 \%$ & Praktis \\
\hline $40 \%<\mathrm{Pv} \leq 60 \%$ & Cukup praktis \\
\hline $20 \%<\mathrm{Pv} \leq 40 \%$ & Kurang praktis \\
\hline $0 \%<\mathrm{Pv} \leq 20 \%$ & Tidak praktis \\
\hline \multicolumn{2}{c}{ Sumber: Riduwan, 2010 }
\end{tabular}

\section{Uji keefektivan bahan ajar}

Uji kefektivan bahan ajar dilihat berdasarkan hasil observasi yang di dapat melalui lembar observasi selama pembelajaran berlangsung dan di analisis menggunakan rumus:

$$
\mathrm{P}=\frac{\text { Perolehan Skor Validasi } 4 \text { Validator }}{\text { Total Skor Maksimal }} \times 100 \%
$$

Hasil persentasi skor akan dikonversikan berdasarkan kategori penilaian yang disajikan dalam tabel 3 .

Tabel 3. Kategori Penilaian Lembar Observasi Kemampuan Berpikir Kritis Siswa

\begin{tabular}{ll}
\hline Nilai Persentase & Kategori \\
\hline $80-100$ & Sangat baik \\
\hline $66-79$ & Baik \\
\hline $56-65$ & Cukup \\
\hline $40-55$ & Kurang \\
\hline $0-39$ & Tidak baik \\
\hline \multicolumn{2}{c}{ Sumber: (Arikunto, 2006) }
\end{tabular}

\section{HASIL DAN PEMBAHASAN}

\section{Uji Kevalidan Bahan ajar Pencemaran lingkungan berbasis PBL}

Untuk mengetahui kevalidan bahan ajar pencemaran lingkungan berbasis PBL maka dilakukan validasi oleh 4 orang validator yang terdiri dari 2 orang ahli materi dan dua orang ahli media. Tujuan dari proses validasi adalah untuk mengetahui kelayakan bahan ajar pencemaran lingkungan berbasis PBL. Hasil validasi para ahli dapat di lihat pada tabel 4.

Tabel 4. Hasil Validasi Bahan Ajar

\begin{tabular}{llll}
\hline No & Aspek & Rata-rata & Kategori \\
\hline 1 & Materi & 88.25 & Sangat Valid \\
\hline
\end{tabular}


DOI : https://doi.org/10.31004/basicedu.v5i6.1730

\begin{tabular}{lll}
\hline $2 \quad$ Media & 98.71 & Sangat Valid \\
\hline Total & 93.48 & Sangat Valid \\
\hline
\end{tabular}

Berdasarkan tabel 4, diketahui bahwa bahan ajar pencemaran lingkungan berbasis PBL yang divalidasi tergolong kategori sangat Valid. Berdasarkan data tersebut dapat disimpulkan bahwa bahan ajar pencemaran lingkungan berbasis PBL layak digunakan dalam tahap uji coba.

\section{Uji Kepraktisan Bahan ajar Pencemaran lingkungan berbasis PBL}

Uji kepraktisan bahan dilakukan pada uji coba skala kecil. Hasil uji kepraktisan bahan ajar pada skala kecil menggunakan respon guru dan siswa yang dapat di lihat pada tabel 5.

Tabel 5. Hasil Uji Kepraktisan Bahan Ajar

\begin{tabular}{llll}
\hline No & Aspek & Rata-rata & Kategori \\
\hline 1 & Guru & 85 & Sangat Praktis \\
\hline 2 & Siswa & 81.19 & Sangat Praktis \\
\hline \multicolumn{2}{l}{ Total } & 83.48 & Sangat Praktis \\
\hline
\end{tabular}

Data pada tabel 5 menunjukkan bahwa rata-rata respon guru dan siswa adalah 83.48 yang tergolong dalam kategori Sangat Praktis. Berdasarkan data tersebut maka dapat disimpulkan bahwa bahan ajar pencemaran lingkungan berbasis PBL sangat praktis untuk digunakan dalam tahap uji coba skala besar.

\section{Uji Keefektivan Bahan ajar Pencemaran lingkungan berbasis PBL}

Uji keefektivan bertujuan untuk mengukur kemampuan berpikir kritis siswa selama proses pembelajaran berlangsung. Uji keefektivan bahan ajar menggunakan lembar observasi kemampuan berpikir kritis siswa dan yang menjadi observer adalah guru mata pelajaran biologi di SMA Kristen 1 Soe. Data uji keefektifan bahan ajar pencemaran lingkungan berbasis PBL dapat dilihat pada tabel 6 .

Tabel 6. Hasil uji keefektifan bahan ajar

\begin{tabular}{llll}
\hline No & Jumlah siswa & Rata-rata & Kategori \\
\hline 1 & 36 & 79.52 & Baik \\
\hline
\end{tabular}

Berdasarkan data pada tabel 6 menunjukkan bahwa bahan ajar pencemaran lingkungan berbasis PBL efektif untuk meningkatkan kemampuan berpikir kritis siswa dilihat dari rata-rata uji keefektifan yang berada pada kategori baik.

Peningkatan kemampuan berpikir kritis siswa di sebabkan karena bahan ajar yang disusun berbasis Model PBL. Model PBL memberikan kesempatan kepada siswa untuk terlibat secara aktif dan menggunakan seluruh pengetahuannya untuk mengkonstruksi dan menemukan konsep-konsep setelah menyelesaiakan permasalahan yang diberikan. Hal ini sejalan dengan pendapatnya (Khanafiyah \& Yulianti, 2013) yang mengatakan bahwa model PBL mengajak siswa untuk bertindak aktif dalam menghadapi dan memecahkan masalah, dan menarik kesimpulan melalui proses berpikir secara alamiah, kritis, logis dan sistematis. Penerapan model PBL dalam pembelajaran, Guru berperan sebagai fasilitator dan siswa sendirilah yang harus mengidentifikasi permasalahan dan mampu memecahkan masalah yang dihadapi. Hal ini sesuai dengan pendapatnya (Puspitasari et al., 2012) mengatakan bahwa Guru menjaga agar pendapat yang dikemukakan siswa tidak melenceng dari tujuan pembelajaran yang ingin di capai pada setiap pertemuan. 
5890 Pengembangan Bahan Ajar Pencemaran Lingkungan Berbasis PBL terhadap Kemampuan Berpikir Kritis Siswa - Nonci Melinda uki, Markus O. Here Bire

DOI : https://doi.org/10.31004/basicedu.v5i6.1730

Model PBL yang digunakan selama penelitian ini memiliki dampak positif bagi siswa. Berdasarkan pengamatan peneliti seluruh siswa terlibat aktif dalam diskusi kelompok, dimana siswa berdiskusi dalam kelompok secara intensif sehingga siswa saling bertanya, menjawab, memberikan ide, mengkritisi dan mengoreksi setiap konsep yang muncul dalam diskusi. Aktivitas ini tentunya menjadi sarana untuk memantapkan pemahaman siswa terhadap konsep yang sedang dipelajari. Selain itu kegiatan diskusi juga memungkinkan siswa untuk mengumpulkan informasi, melakukan penyelidikan dan membuat kesimpulan, dengan demikian secara tidak langsung semua kegiatan ini akan membuat siswa aktif dalam mengikuti pembelajaran dan dapat meningkatkan kemampuan berpikir kritis siswa.

Kemampuan berpikir kritis merupakan hal sangat penting dalam proses pembelajaran. didukung dengan pendapatnya (Kazempour, 2013) mengatakan bahwa mengajarkan siswa untuk berpikir kritis merupakan salah satu tujuan utama pendidikan. Berpikir kritis memungkinkan siswa untuk menemukan kebenaran di tengah banjir kejadian dan informasi yang mengelilingi mereka setiap hari (Johnson. E.B, 2008). Setiap siswa secara lahiriah telah mempunyai kemampuan berpikir kritis, tetapi dalam perkembangannya banyak faktor dapat mempengaruhi penurunan kemampuan ini (Dian R.S et al., 2015). Oleh karena itu melalui pendidikan sekolah, para siswa dididik untuk mampu memecahkan masalah-masalah yang terjadi di dalam pembelajaran. Hal ini sesuai dengan pendapatnya (Tanjung \& Nababan, 2018) mengatakan bahwa pembiasaan berpikir kritis secara bertahap memiliki kecenderungan membuat anak memandang berbagai hal dengan rasa ingin tahu. Sejalan dengan pendapatnya (Lilis et al., 2018) mengatakan bahwa pemikir kritis mampu mengkritisi, bertanya, mengevaluasi, dan merefleksi informasi yang diperoleh.

Penelitian ini menunjukkan bahwa, bahan ajar pencemaran lingkungan berbasis PBL yang dikembangkan valid, praktis dan efektif digunakan dalam proses pembelajaran. Penelitian ini juga di dukung dengan penelitian yang dilakukan oleh (Setyorini et al., 2011) hasil penelitiannya menunjukkan bahwa PBL dapat meningkatkan kemampuan berpikir kritis siswa. Sejalan dengan penelitian yang dilakukan oleh (Al-Fikry et al., 2018) hasil penelitiannya menyimpulkan bahwa pembelajaran model PBL pada materi sistem ekskresi di SMA N 1 Singorojo meningkatkan kemampuan berpikir kritis siswa. Penelitian yang dilakukan oleh (Herzon et al., 2018) hasil penelitiannya menyimpulkan bahwa model PBL cukup efektif untuk meningkatkan keterampilan berpikir kritis belajar peserta didik pada materi kalor. Peningkatkan kemampuan berpikir kritis siswa juga dipengaruhi oleh model pembelajaran yang digunakan.

\section{KESIMPULAN}

Berdasarkan hasil penelitian, dapat disimpulkan bahwa pengembangan bahan ajar pencemaran lingkungan berbasis PBL valid, praktis dan efektif untuk di gunakan dalam proses pembelajaran.

\section{UCAPAN TERIMA KASIH}

Terimakasih kepada Kemenristekdikti yang telah memberikan dana kepada penulis untuk melakukan penelitian ini \& juga terimakasih kepada STKIP Soe yang mendukung penulis dalam penelitian ini.

\section{DAFTAR PUSTAKA}

Al-Fikry, I., Yusrizal, Y., \& Syukri, M. (2018). Pengaruh Model Problem Based Learning Terhadap Kemampuan Berpikir Kritis Peserta Didik Pada Materi Kalor. Jurnal Pendidikan Sains Indonesia, 6(1), 17-23. Https://Doi.Org/10.24815/Jpsi.V6i1.10776

Arikunto, S. (2006). Statistika Penelitian, Dasar-Dasar Evaluasi Pendidikan. Pt Bumi Aksar.

Damanik, D. P., \& Bukit, N. (2013). Analisis Kemampuan Berpikir Kritis Dan Sikap Ilmiah Pada 
5891 Pengembangan Bahan Ajar Pencemaran Lingkungan Berbasis PBL terhadap Kemampuan Berpikir Kritis Siswa - Nonci Melinda uki, Markus O. Here Bire

DOI : https://doi.org/10.31004/basicedu.v5i6.1730

Pembelajaran Fisika Menggunakan Model Pembelajaran Inquiry Training (It) Dan Direct Instruction (Di). Jurnal Pendidikan Fisika, 2(1), 16-24.

Departemen Pendidikan Nasional. (2008). Panduan Pengembangan Bahan Ajar. Depdiknas.

Dian R.S, Setiati, N., \& Indriyanti, D. R. (2015). Pengembangan Pembelajaran Bermodelkan Example Non Example Berorientasi Pada Kemampuan Berpikir Kritis Dan Hasil Belajar Siswa. Lembaran Ilmu Kependidikan, 44(1), 24-32.

Hamruni. (2011). Strategi Pembelajaran. Insan Madani.

Herzon, H. H., Budijanto, B., \& Utomo, D. H. (2018). Pengaruh Problem-Based Learning (Pbl) Terhadap Keterampilan Berpikir Kritis. Jurnal Pendidikan: Teori, Penelitian, Dan Pengembangan, 3(1), 42-46. Http://Journal.Um.Ac.Id/Index.Php/Jptpp/Article/View/10446

Johnson. E.B. (2008). Contextual Teaching \& Learning. Mizan Learning Center (Mlc).

Kazempour, E. 2013. The Effects Of Inquiry-Based Teaching On Critical Thingking Of Student. Journal Of Social. Issues \& Humanities, 1(3), 23-27

Khanafiyah, S., \& Yulianti, D. (2013). Model Problem Based Instruction Pada Mengembangkan Sikap Kepedulian Lingkungan. Jurnal Pendidikan Fisika Indonesia (Indonesian Journal Of Physics Education), 9(1), Pp 35-42.

Lilis Nuryanti., Siti Zubaidah \& Markus Diantoro. 2018. Kemampuan Berpikir Kritis Siswa Smp. Jurnal Pendidikan: Teori, Penelitian, Dan Pengembangan, Vol. 3, No. 2

Lestari, I. (2013). Pengembangan Bahan Ajar Berbasis Kompetensi. Akademi Remaja.

Liliasari. (2011). Pengembangan Keterampilan Generik Sains Untuk Meningkatkan Kemampuan Berpikir Kritis Peserta Didik (Makalah-Jont-Sem Uitm).

Puspitasari, L., Santosa, S., \& Harlita. (2012). The Influence Of Problem Based Learning Model Towards Studentâs Creative Thinking Skill In Biology Grade X At Sma Negeri 2 Surakarta In Academic Year 2011/2012. Bioedukasi, 5(2), 61-72. Https://Doi.Org/10.20961/Bioedukasi-Uns.V5i2.3934

Rusman. (2012). Model-Model Pembelajaran. Raja Grafindo Persada.

Setyorini, U., Sukiswo, S. E., \& Subali, B. (2011). Penerapan Model Problem Based Learning Untuk Meningkatkan Kemampuan Berpikir Kritis Siswa Smp. Jurnal Pendidikan Fisika Indonesia, 7(1), 52 56. Https://Doi.Org/10.15294/Jpfi.V7i1.1070

Setyowati, A., \& Subali, B. (2011). Implementasi Pendekatan Konflik Kognitif Dalam Pembelajaran Fisika Untuk Menumbuhkan Kemampuan Berpikir Kritis Siswa Smp Kelas Viii. Jurnal Pendidikan Fisika Indonesia, 7(2), 89-96. Https://Doi.Org/10.15294/Jpfi.V7i2.1078

Sudarma, M. (2013). Mengembangkan Keterampilan Berpikir Kritis. Rajawali Press.

Tanjung, H. S., \& Nababan, S. A. (2018). Pengembangan Perangkat Pembelajaran Matematika Berorientasi Model Pembelajaran Berbasis Masalah (Pbm) Untuk Meningkatkan Kemampuan Berpikir Kritis Siswa Sma Se-Kuala Nagan Raya Aceh. Genta Mulia, 9(2), 56-70.

Toharudi, U., S., H., \& Rustaman. (2011). Membangun Literasi Sains Peserta Didik. Pendidikan. 